\title{
The Relationship between Academic Procrastination Behaviors of Preservice Science Teachers and Their Attitudes toward Social Media
}

\author{
Hülya ASLAN $\mathrm{EFE}^{1}$ æ \\ Rıfat EFE ${ }^{2}$ \\ 'Asist. Prof.; Dicle University, Ziya Gökalp Education Faculty, Department of Science Education. Diyarbakır- \\ Turkey \\ Email:hulyaefe@dicle.edu.tr.Tel:0505451 \\ 'Assoc. Prof.; Dicle University, Ziya Gökalp Education Faculty, Department of Biology Education. Diyarbakir- \\ Turkey \\ Email:rifatefe@hotmail.com Tel:0533708
}

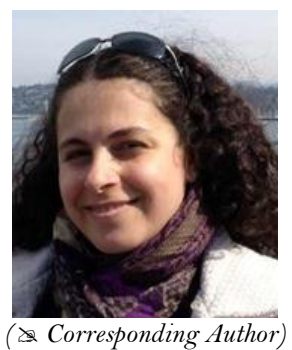

\begin{abstract}
In this study, the relationship between study preservice science teachers' academic procrastination and their attitudes toward social media was investigated. The study was carried out with the participation of 511 preservice science teachers (F: 346, M:165) on teacher education course at Dicle University during 2014-2015 academic year. The date was collected through "Social Media Attitude Scale" and "Academic Procrastination Scale". The data collected was analyzed by using $\mathrm{t}$ test, one-way Anova and multiple regression. Analysis of the data revealed that academic procrastination was higher among male preservice science teachers in comparison to the female participants. The study also found that having social media membership positively affects the preservice teachers' attitude in terms of social sharing, social competency and social isolation. The study also revealed that the duration of membership for a social media site has an influence on academic procrastination. The multiple regression displayed that as social media attitude dimensions, the sharing need, social competency, social isolation and relationship with teachers' variables all together yield a low-level and significant relationship with preservice teachers' academic procrastination behaviors. The findings have important implications for teacher education.
\end{abstract}

Keywords: Academic procrastination, Social media attitudes, Preservice teachers.

Citation | Hülya ASLAN EFE; Rıfat EFE (2018). The Relationship between Academic Procrastination Behaviors of Preservice Science Teachers and Their Attitudes toward Social Media. Journal of Education and e-Learning Research, 5(2): 102-109. History:

Received: 6 April 2018

Revised: 9 April 2018

Accepted: 10 April 2018

Published: 12 April 2018

Licensed: This work is licensed under a Creative Commons

Attribution 3.0 License (oc)

Publisher:Asian Online Journal Publishing Group
Contribution/Acknowledgement: Both authors contributed to the conception and design of the study.

Funding: This study received no specific financial support.

Competing Interests: The authors declare that they have no conflict of interests.

Transparency: The authors confirm that the manuscript is an honest, accurate, and transparent account of the study was reported; that no vital features of the study have been omitted; and that any discrepancies from the study as planned have been explained.

Ethical: This study follows all ethical practices during writing.

\section{Contents}

1. Introduction

2. Method.

104

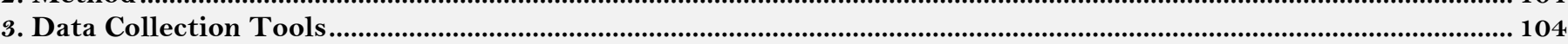

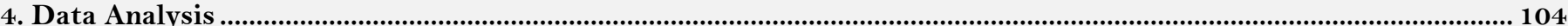

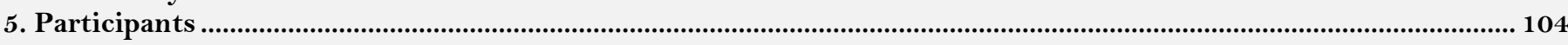

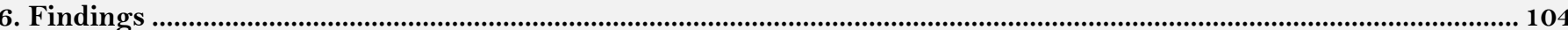

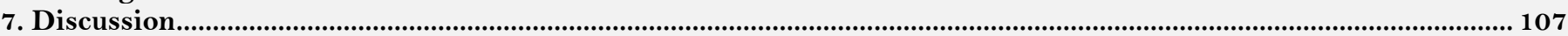

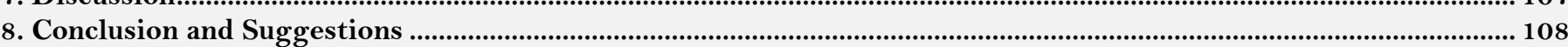

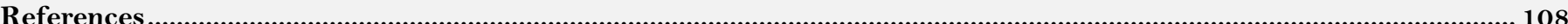




\section{Introduction}

Almost everybody is obliged to carry out certain tasks besides having duties to perform and responsibilities to fulfil in many areas of life. However, due to various reasons, it is a commonly observed and experienced phenomenon that tasks or responsibilities are postponed and left to the last minute. As stated by Burka and Yuen (1983) people who are disturbed by such behaviour, although they promise never to procrastinate again, find themselves recurrently in the same procrastination cycle. Procrastination is defined as the irrational and deliberate postponement of an intention to carry out an action (Johnson et al., 2000; Klassen and Kuzucu, 2009). When the research literature about the causes of procrastination behaviour is reviewed, it is clear that education specialists have recently been focusing on the issue of academic procrastination and trying to find out the possible causes of academic procrastination behaviour (Akinsola et al., 2007; Dietz et al., 2007; Hen and Goroshi, 2014). Academic procrastination behaviour is described as leaving homework, test preparation or final projects to the last minute (Solomon and Rothblum, 1984). The relevant research show that a significant number of students exhibit such academic procrastination behaviour (Solomon and Rothblum, 1984; Potts, 1987; Haycock, 1993; Day et al., 2000; Onwuegbuzie, 2000). Majority of this research establishes that academic procrastination behaviour is very common among university students. Born in 1990s and currently university students, the new generation spend most of their time on social media. They were born into technology and they add a new gadget to their electronic repertories every year. They make friends through social media, send text messages rather than talking on their phones and they sleep with their phones so that they can follow their tweets (Kirschner and Karpinski, 2010). As a result, they are described as the age group that use the Internet most frequently (Kandell, 1998; Oguz et al., 2008). Therefore, when recent studies are analysed, the relationship of technology use with academic procrastination is found to be a common research focus (Ferrari, 2010; Humprey and Harbin, 2010; Davis and Abbitt, 2013). This is because the studies analysing the procrastination behaviour have concluded that failure of task accomplishment due to engagement in pleasurable activities may be related to Internet use (Ellis and Knaus, 1977; Schouwenburg, 2004). Indeed, a negative relationship between technology use and academic procrastination is supported by the relevant literature (Aypay et al., 2007; Waight and Abd-El-Khalick, 2007). Internet-based, new communication environments are constantly being developed and improved. New communication technologies offer people new environments to share their feelings and thoughts. These virtual environments called social networking sites can be described as the virtual realities through which people try to satisfy their real life needs. The expanding coverage of the Internet and involvement of people from every age group with technology have led to the emergence of social networks, which are interactive environments. Individuals' interactions on the Internet form the social media. Social media are described as the web sites that are based on Web 2.0 technologies that allow having deeper social interactions, forming communities and realizing cooperative projects (Akar, 2010). Blogs, tweets that are defined as micro blogs, chat sites, forums, and social networking sites are a part of social media and while they seem to occur among small groups, they increase high-speed information sharing. Social media has a structure that encompasses everybody involved. Thanks to its participants its content is enriched and a mutual interaction is ensured. This environment, where participants can express themselves without any interference, allows the formation of groups that gather around certain issues (Mayfield, 2008). This causes individuals to use social media extensively. According to the findings of a study conducted by EDUCAUJE Centre for Applied Research (ECAR) with the participation of 36.950 university students, $90 \%$ of university students use social media sites. A study by Junco (2012) found that university students spend about 1 hour 40 minutes daily on social media. However, some studies have found that students overuse the social media, drawn by the unlimited opportunities the Internet offers and its popularity (Chou et al., 2005). Furthermore, Silver and Sabini (1981) caution that even the small breaks that university students take on the Internet during their academic studies tend to turn into academic procrastination and these small time periods in which studies are postponed may gradually get longer and longer. Thus, students' spending their time on social media sites instead of on academic work leads them to postpone their academic work (Chickering and Gamson, 1987). Young (2004) shows that, as many people spend most of their time on the Internet due to its attractiveness, their work and school productivity drops as the length of Internet use increases. A study carried out in Alfred University found that $43 \%$ of highly intelligent students failed their courses due to spending time on the university web until late hours. Kubey et al. (2001) study involving 576 university students found that $9.3 \%$ of them were internet addicts and their academic performance was four times lower than the non-addict group's. When the studies focusing on the relationship between academic procrastination and social media are analysed, it is seen that there is non-existent or very little research involving preservice teachers. When the role teachers have in education and the procrastination that can occur during the planning, preparation, application and evaluation stages of teaching are considered, the significance of preservice teachers' procrastination behaviours is better understood. In an environment where the use of social media in education is becoming more and more popular, the relationship between the use of social media by teacher candidates and their academic procrastination behaviour is also getting increasingly important. Hence, the purpose of this study is to analyse the effect of social media use, which is increasingly popular among young adults, on academic procrastination behaviour. Accordingly, the research questions are as follows:

1. Is there a significant difference between science pre-service teachers' academic procrastination behaviours and their attitudes towards social media on the basis of the gender variable?

2. Is there a significant difference between science pre-service teachers' academic procrastination behaviours and their attitudes towards social media on the basis of the social media membership variable?

3. Is there a significant difference between science pre-service teachers' academic procrastination behaviours and their attitudes towards social media on the basis of the duration of social media membership variable?

4. Is there a significant difference between science pre-service teachers' academic procrastination behaviours and their attitudes towards social media on the basis of the subscribed social media site variable?

5. Do attitudes towards social media predict academic procrastination behaviour? 


\section{Method}

In the study, a comparative relational screening model in descriptive survey model was used as the research method. Survey method is a research method that aims to describe a past or present phenomenon as is. As a general survey model, the relational screening model aims to determine the existence and degree of the covariance between two or more variables. In the relational screening model, covariation variables are symbolized separately. This symbolization is also done to allow a relational analysis (Karasar, 2000).

\section{Data Collection Tools}

The "Social Media Attitude Scale" developed for students by Otrar and Argun (2013) was used as the data collection tool in this study. A 5 point Likert type 23 item scale (6 negative and 17 positive) consists of 4 factors (need for sharing, social competency, social isolation and relationship with teachers). The internal consistency analyses conducted for Otrar and Argun (2013) study calculated the Cronbach alpha reliability coefficient as .85 for the whole scale. For the present study, the Cronbach alpha reliability coefficient was found as .82 for the whole test.

In order to determine preservice science teachers' academic procrastination behaviours, the 19 item "Academic Procrastination Scale" developed by Çakıcı (2003) was used. A high score on this scale indicates that the individual is a procrastinator. The scale is used unidimensional. Cronbach alpha reliability coefficient of this academic procrastination scale was found to be .92 by Çakıcı (2003). For the current study, the Cronbach alpha reliability coefficient of the scale was found to be .85 .

\section{Data Analysis}

$\mathrm{t}$ test was used to compare preservice science teachers' academic procrastination behaviours and their attitudes towards social media on the basis of gender and social media membership status variables. One-Way ANOVA test was used to find out preservice science teachers' academic procrastination behaviours and their attitudes towards social media on the basis of the variables of social media membership duration and most frequently used social media sites. Furthermore, multiple regression analysis was used to find out whether preservice science teachers' attitudes towards social media are predictors of their academic procrastination behaviours.

\section{Participants}

In this study, which uses the survey method, the sample group consists of the preservice science teachers studying at Dicle University Ziya Gökalp Faculty of Education in the 2014-2015 academic year. The data were collected during the Fall and Spring semesters. Of the 511 preservice teachers participating in the study from Ziya Gökalp Faculty of Education, 346 are females and 165 are males.

\section{Findings}

In this section, preservice science teachers' academic procrastination behaviours and their attitudes towards social media are analysed according to the variables of gender, social media site membership, social media site membership duration and most frequently used social media sites. In addition, whether preservice science teachers' attitudes towards social media predict their academic procrastination behaviours is determined.

Table-1. Comparison of the Academic Procrastination and Attitude Towards Social Media Dimensions by Gender Variable

\begin{tabular}{|c|c|c|c|c|c|c|c|}
\hline & Gender & $\mathbf{N}$ & Mean & SD & df & $t$ & p \\
\hline \multirow[t]{2}{*}{ Academic Procrastination } & Female & 346 & 2,7504 & ,66668 & \multirow[t]{2}{*}{509} & \multirow[t]{2}{*}{$-3,271$} & \multirow[t]{2}{*}{$.001^{*}$} \\
\hline & Male & 165 & 2,9537 &, 63674 & & & \\
\hline \multirow{2}{*}{ Sharing need } & Female & 346 & 2,8320 & ,80763 & \multirow[t]{2}{*}{509} & \multirow[t]{2}{*}{,405 } & \multirow[t]{2}{*}{.686} \\
\hline & Male & 165 & 2,8000 & ,89372 & & & \\
\hline \multirow[t]{2}{*}{ Social Competency } & Female & 346 & 2,5328 &, 75109 & \multirow[t]{2}{*}{509} & \multirow[t]{2}{*}{$-1,417$} & \multirow{2}{*}{.157} \\
\hline & Male & 165 & 2,6394 &, 88178 & & & \\
\hline \multirow{2}{*}{ Social Isolation } & Female & 346 & 3,5636 & ,99206 & \multirow[t]{2}{*}{509} & \multirow[t]{2}{*}{1,656} & \multirow[t]{2}{*}{.098} \\
\hline & Male & 165 & 3,4091 &, 97417 & & & \\
\hline \multirow[t]{2}{*}{ Relationship with Teacher } & Female & 346 & 2,7351 & 1,08991 & \multirow[t]{2}{*}{509} & \multirow[t]{2}{*}{2,315} & \multirow[t]{2}{*}{$.021^{*}$} \\
\hline & Male & 165 & 2,4990 & 1,05256 & & & \\
\hline
\end{tabular}

(2012) Independent t-test impressions

The results of the comparison of preservice science teachers' academic procrastination and their attitude towards social media dimension means based on gender variable can be seen in Table 1. These results indicate that, there is a statistically significant difference between preservice science teachers' academic procrastination behaviours based on the gender variable $(\mathrm{p}<.05)$. This difference is in favour of the female students. Similarly, a significant difference was found by gender in favour of female students for the dimension of relationship with teacher, as one of the dimensions regarding preservice science teachers' attitudes towards social media $(\mathrm{p}<.05)$. As dimensions of attitude towards social media, sharing need, social competency and social isolation dimensions' means comparison by gender did not yield a significant difference $(p>.05)$. When the mean scores for the sharing need and social isolation dimensions are analysed, it is clear that female students' means are higher than the males'. However, male students' social competency means are higher than the females. 
Table-2. Comparison of the Dimensions of Academic Procrastination and Attitude Towards Social Media by the Variable of Social Media Membership

\begin{tabular}{|c|c|c|c|c|c|c|c|}
\hline & $\begin{array}{ll}\text { Social } & \text { Media } \\
\text { Membership } & \\
\end{array}$ & $\mathbf{N}$ & Mean & SD & df & $t$ & $\mathbf{p}$ \\
\hline \multirow[t]{2}{*}{ Academic Procrastination } & Have & 437 & 2,8345 &, 66443 & 509 & \multirow[t]{2}{*}{1.441} & \multirow[t]{2}{*}{.150} \\
\hline & Does not have & 74 & 2,7134 &, 65234 & & & \\
\hline \multirow[t]{2}{*}{ Sharing need } & Have & 437 & 2,8924 & ,79533 & \multirow[t]{2}{*}{509} & \multirow[t]{2}{*}{4.750} & \multirow[t]{2}{*}{$.000^{*}$} \\
\hline & Does not have & 74 & 2,4037 & ,94533 & & & \\
\hline \multirow[t]{2}{*}{ Social Competency } & Have & 437 & 2,6214 &, 77728 & \multirow[t]{2}{*}{509} & \multirow[t]{2}{*}{3.752} & \multirow[t]{2}{*}{$.000^{*}$} \\
\hline & Does not have & 74 & 2,2500 & ,83823 & & & \\
\hline \multirow[t]{2}{*}{ Social Isolation } & Have & 437 & 3,5862 & ,95840 & \multirow[t]{2}{*}{509} & \multirow[t]{2}{*}{4.092} & \multirow[t]{2}{*}{$.000^{*}$} \\
\hline & Does not have & 74 & 3,0856 & 1,05670 & & & \\
\hline \multirow[t]{2}{*}{ Relationship with Teacher } & Have & 437 & 2,6827 & 1,08130 & \multirow[t]{2}{*}{509} & \multirow[t]{2}{*}{1.211} & \multirow[t]{2}{*}{.227} \\
\hline & Does not have & 74 & 2,5180 & 1,08700 & & & \\
\hline
\end{tabular}

Source: Büyüköztürk (2012) Independent t-test impressions

Table 2 shows the results of the means comparison of preservice science teachers' academic procrastination and their attitude towards social media by the variable of social media site membership. These results indicate preservice science teachers' attitudes towards social media in the subdimensions of sharing need, social competency and social isolation have a significant difference by social media membership variable $(\mathrm{p}<.05)$. But the relationship with teacher as a subdimension of attitude towards social media by social media site membership variable did not display a significant difference $(\mathrm{p}>.05)$. Likewise, preservice science teachers' academic procrastination behaviour by social media site membership variable is found not to show a significant difference ( $p>.05)$. Besides, when the means are analysed, preservice science teachers with social media site membership can be said to demonstrate a higher degree of academic procrastination behaviour and a higher degree of communication with teachers.

Table-3. The Anova Result Regarding the Dimensions of Academic Procrastination and Attitude Towards Social Media by the Variable of Social Media Site Membership Duration

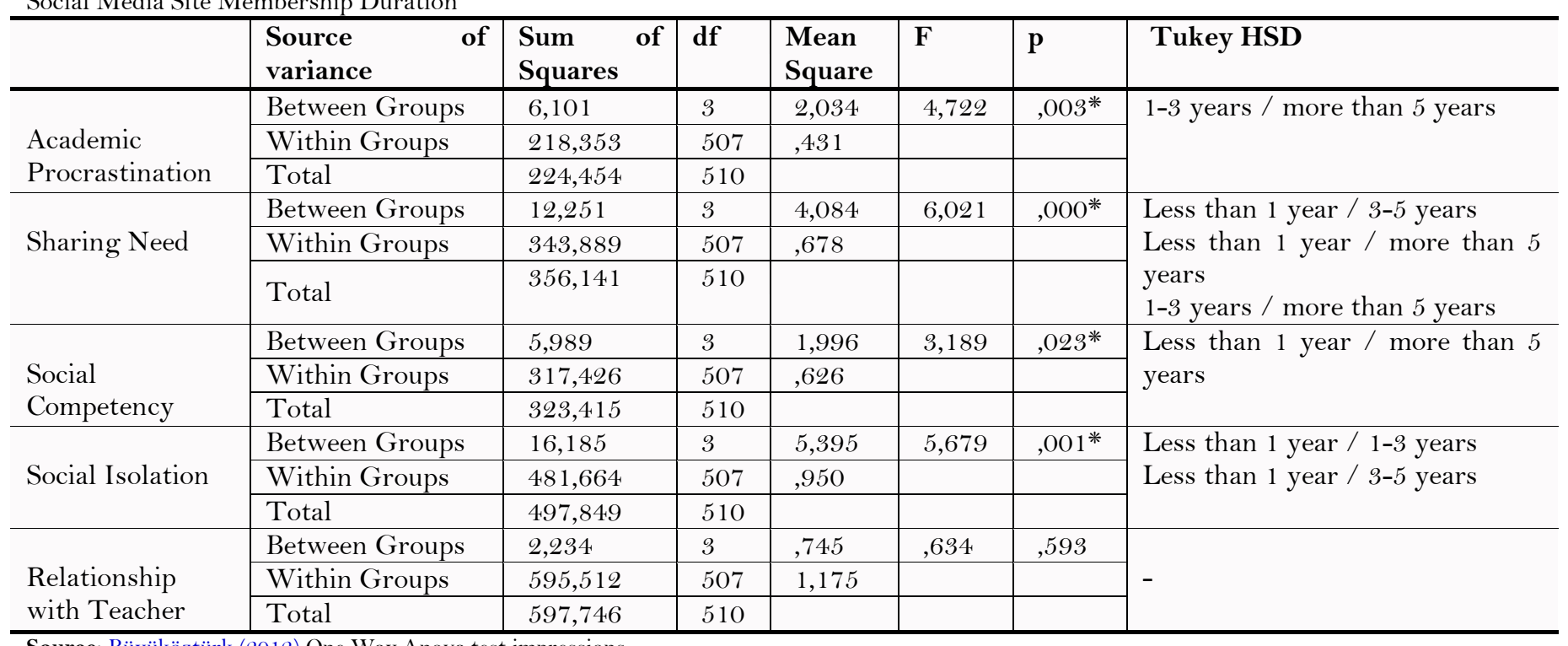

Source: Büyüköztürk (2012) One Way Anova test impressions

Table 3 shows the results of the one-way analysis of variance of the means of preservice science teachers' academic procrastination and attitude towards social media subdimensions, by the social media site membership duration variable. Table 3 clearly shows that based on the social media site membership duration variable, there is a statistically significant difference among preservice science teachers' academic procrastination behaviours $\left(\mathrm{F}_{(3-}\right.$ $\left.{ }_{507}=4.722, \mathrm{p}<0.05\right)$. The results of the Tukey HSD analysis indicate that academic procrastination behaviour of preservice teachers with 5 years or longer social media site membership $(\bar{X}=2.96)$ is significantly higher than preservice teachers with 1-3 years of membership $(\bar{X}=2.70)$. It can also be clearly seen that there is a statistically significant difference within the sharing need subdimension by social media site membership duration variable $\left(\mathrm{F}_{(3-}\right.$ $\left.{ }_{507)}=6.021, \mathrm{p}<0.05\right)$. The Tukey HSD analysis results show that social media sharing needs of preservice science teachers with less than 1 year of membership to social media sites are significantly different $(\bar{X}=2.55)$ from preservice teachers with $3-5$ years of membership $(\bar{X}=2.88)$. Similarly, the social media sharing needs of preservice teachers with less than 1 year of social media membership are found to be significantly different $(\overline{\mathrm{X}}=$ 2.55) from preservice teachers with 5 years or longer membership $(\bar{X}=2.98)$. Also, the social media sharing needs of preservice teachers with less than 1-3 years of social media membership $(\bar{X}=2.69)$ are significantly different from preservice teachers with 5 years or longer membership $(\bar{X}=2.98)$. These results indicate that, as the length of social media site membership duration increases preservice science teachers' need for sharing on social media does so as well. The analysis of Table 3 reveals that, there is a statistically significant difference among preservice science teachers' social competencies by the variable of social media site membership duration $\left(\mathrm{F}_{(3-507)}=3.189\right.$, $\mathrm{p}<0.05)$. The results of the Tukey HSD analysis indicate that this significance is between the preservice science teachers with less than 1 year of membership to social media sites $(\bar{X}=2.41)$ and the preservice teachers with more than 5 years of membership $(\bar{X}=2.71)$. Furthermore, while there is no significant difference, when the means are analysed, it draws attention that the longer the duration of social media site membership, the higher are the means of social competency. Table 3 demonstrates that, there is a statistically significant difference among 
preservice science teachers' social isolations by the variable of social media site membership duration $\left(\mathrm{F}_{(3-}\right.$ $\left.{ }_{507}=5.679, \mathrm{p}<0.05\right)$. When the results from the Tukey HSD analysis conducted to determine the direction of this significant difference are analysed, social isolation of preservice teachers with social media membership of 3-5 years $(\bar{X}=3.67)$ can be seen to be significantly higher than those with less than 1 year of membership $(\bar{X}=3.21)$. Likewise, the social isolation of preservice teachers with 1-3 year membership is significantly higher $(\overline{\mathrm{X}}=3.67)$ than preservice teachers with less than 1 year of social media site membership $(\bar{X}=3.21)$. But no statistically significant difference has been found among preservice science teachers regarding their relationships with their teachers based on the variable of social media site membership duration $\left(\mathrm{F}_{(3-507)}=.634, \mathrm{p}>\right.$.05). Table 4 shows the one-way variance analysis results of the means of preservice science teachers' academic procrastination and attitude towards social media subdimensions, by the variable of social media site membership duration. Table 4 indicates that there is no statistically significant difference among preservice science teachers' academic procrastination behaviours by the variable of most frequently used social media sites $\left(\mathrm{F}_{(4-506)}=.678\right.$, p $\left.>0.05\right)$. A statistically significant difference can be seen in preservice science teachers' sharing needs by most frequently used social media sites variable $\left(\mathrm{F}_{(4-506)}=7.503, \mathrm{p}<0.05\right)$. Tukey HSD analysis results indicate that the preservice science teachers using Facebook with the highest frequency $(\bar{X}=2.93)$ have significantly higher needs to share on social media than the preservice teachers using YouTube the most frequently $(\overline{\mathrm{X}}=2.42)$.

Table-4. The Anova Result Regarding the Dimensions of Academic Procrastination and Attitude Towards Social Media by the Variable of Subscribed Social Media Sites

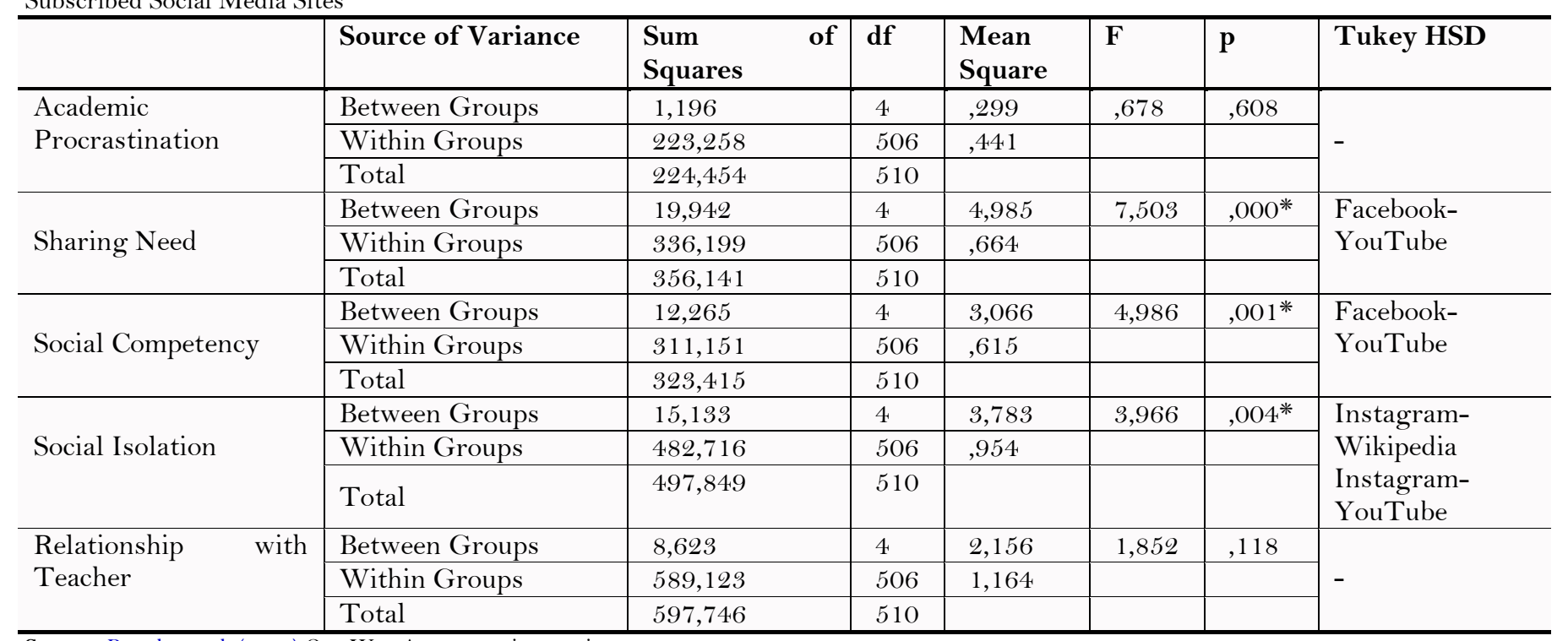

Source: Büyüköztürk (2012) One Way Anova test impressions

Table 4 also shows that the subdimension of preservice science teachers' social competency demonstrates a statistically significant difference by the variable of most frequently used social media sites $\left(\mathrm{F}_{(4-506)}=4.986, \mathrm{p}<0.05\right)$. The results of the Tukey HSD analysis reveal that this significance appears between the preservice science teachers that use Facebook the most frequently $(\bar{X}=2.66)$ and the preservice teachers that use YouTube the most frequently $(\overline{\mathrm{X}}=2.27)$. It can also be seen that there is a statistically significant social isolation difference among preservice science teachers by the variable of the most frequently used social media sites $\left(\mathrm{F}_{(4-506)}=3.966, \mathrm{p}<0.05\right)$. When the results of the Tukey HSD analysis carried out to find the direction of this significant difference are analysed, the social isolation of the preservice teachers who use Instagram the most often is found to be significantly higher $(\bar{X}=4.05)$ than those that use Wikipedia the most often $(\bar{X}=3.15)$. In a similar way, the most frequent Instagram-using preservice teachers' $(\bar{X}=4.05)$ social isolation is significantly higher than the preservice teachers' that use YouTube the most frequently $(\overline{\mathrm{X}}=3.25)$. When the social isolation mean scores are analysed by most frequently used social media sites, it is seen that Instagram has the highest means $(\bar{X}=4.05)$. Instagram is followed by Facebook ( $\overline{\mathrm{X}}=3.56)$, Twitter $(\overline{\mathrm{X}}=3.48)$, YouTube $(\overline{\mathrm{X}}=3.25)$ and Wikipedia $(\overline{\mathrm{X}}=3.15)$, respectively. However, no statistically significant difference is found between preservice science teachers in the subdimension of relationship with teachers by the variable of most frequently used social media sites $\left(\mathrm{F}_{(4-506)}=1.852, \mathrm{p}>.05\right)$.

Table-5. Multiple Regression Analysis Results Regarding the Prediction of Academic Procrastination

\begin{tabular}{|c|c|c|c|c|c|c|c|c|}
\hline $\begin{array}{l}\text { Dependent } \\
\text { Variable }\end{array}$ & Predictors & $\bar{B}$ & Std. Error & $\boldsymbol{\beta}$ & $\bar{t}$ & $\bar{p}$ & Zero order & Partial \\
\hline \multirow{6}{*}{ Academic Procrastination } & Constant & 2.842 & .157 & - & 18.110 & $.000^{*}$ & - & - \\
\hline & Sharing Need & .126 & .051 & .159 & 2.462 & $.014^{*}$ & .174 & .109 \\
\hline & Social Competency & .042 & .053 & .050 & .785 & .433 & .153 & .035 \\
\hline & Social Isolation & -.110 & .029 & -.164 & -3.754 & $.000^{*}$ & -.175 & -.162 \\
\hline & $\begin{array}{l}\text { Relationship with } \\
\text { Teacher }\end{array}$ & -.039 & .032 & -.063 & -1.209 & .227 & .066 & -.052 \\
\hline & $\begin{array}{ll}\mathrm{R}=.245 & \mathrm{R}^{2}=.060 \\
\mathrm{~F}=8.051 & \mathrm{p}=.000^{*}\end{array}$ & & & & & & & \\
\hline
\end{tabular}

Source: Büyüköztürk (2012) Multiple Regression test impressions

The regression analysis results regarding the prediction of academic procrastination by the variables of sharing need, social competency, social isolation and relationship with teachers are given in Table 5 . When the binary and 
partial correlations between the predictor variables and predicted variables are analysed, a positive and low-level relationship $(\mathrm{r}=0.17)$ is found between the sharing need subdimension and academic procrastination behaviour, but when the other variables are controlled, the correlation between the two variables is calculated as $r=0.10$. There is a positive and low-level $(\mathrm{r}=0.15)$ relationship between the social competency dimension and academic procrastination behaviour. However, when the other three variables are controlled, this correlation is calculated as $r=0.03$. The negative and low binary correlation $(r=-0.17)$ calculated for the social isolation dimension and academic procrastination behaviour is still negative and low ( $r=-0.16)$ when the other three variables are controlled. A positive and low-level relationship $(\mathrm{r}=0.06)$ is also found between the subdimension of relationship with teachers and academic procrastination behaviour, however, it is still negative and low-level ( $r=-0.05)$ when the other three variables are controlled.

As social media attitude dimensions, the sharing need, social competency, social isolation and relationship with teachers' variables all together yield a low-level and significant relationship with preservice teachers' academic procrastination behaviours $\left(\mathrm{R}=.245, \mathrm{R}^{2}=.060, \mathrm{p}<.01\right)$. With these four variables, academic procrastination behaviour explains $6 \%$ of the total variance.

According to the standardized regression coefficient $(\beta)$, predictor variables' relative order of importance on academic procrastination is: social isolation, sharing need, relationship with teachers and social competency. When the t-test results regarding the significance of regression coefficients are analysed, it is seen that social isolation variable is a negative and significant predictor of academic procrastination behaviour. This result can be interpreted as the higher the social isolation, the lower the academic procrastination will be. The t-test results regarding the significance of regression coefficients indicate that the variable of sharing need is a positive and significant predictor of the academic procrastination behaviour. That is, as the need for sharing on social media increases so does the academic procrastination behaviour.

\section{Discussion}

In this study, the relationship between preservice science teachers' academic procrastination behaviours and their attitude towards social media is sought to be determined. The study revealed that, there is a significant difference in favour of female preservice teachers in academic procrastination when gender is considered. The relevant literature includes many studies focusing on academic procrastination behaviour by gender. Some of these studies assert that there is no gender difference regarding academic procrastination behaviour(Solomon and Rothblum, 1984; Ferrari, 1991; Ferrari, 1992;2000; Kachgal et al., 2001) while some others maintain that female students display a higher degree of academic procrastination (Doyle and Paludi, 1998; Washington, 2004). Some study findings support the present study (Senécal et al., 1995; Prohaska et al., 2000; Balkıs et al., 2006; Balkıs, 2007). No significant difference could be found through the comparison of the means of sharing need, social competency and social isolation as dimensions of attitude towards social media by gender variable. However, a significant gender difference has been found in favour of female preservice science teachers in the subdimension of relationship with teachers as an attitude towards social media dimension. Argine (2013) concludes that the subdimension of relationship with teachers does not indicate any difference by the variable of gender.

Another result of the study is, the sharing need, social competency and social isolation subdimensions of the preservice science teachers' social media attitude scale indicate a significant difference by the variable of social media membership. On the contrary, relationship with teachers subdimension of the attitude towards social media dimension does not indicate a significant difference by the variable of social media site membership. Similarly, preservice science teachers' academic procrastination behaviours have been found not to show a significant difference by social media site membership.

There is a statistically significant difference among preservice science teachers' academic procrastination behaviours by the variable of social media site membership duration. Academic procrastination behaviour of preservice teachers with social media site membership of 5 years or longer is significantly higher than those with 13 year membership. A study by Pychyl et al. (2000) found that pleasurable short-term activities with special prizes guide procrastination behaviour. Therefore, providing fun and pleasure through online activities by diversion may compound such procrastination behaviour. It can be seen that there is a statistically significant difference in preservice science teachers' sharing need subdimension by the variable of social media site membership duration. Sharing need of preservice teachers with longer social media membership is higher. A statistically significant difference has been identified among preservice science teachers' social competencies by social media site membership duration. Additionally, preservice teachers with longer membership duration have been found to have higher social media competency. As preservice science teachers' social media site membership duration rises their social isolation increases significantly as well. Some studies have found that negative emotions affect internet-based procrastination. Kraut et al. (1998) emphasize that people who spend most of their time online experience deeper depression and loneliness because the increased time spent online coupled with high number of virtual sharers distance them from real life and other real people and thus negatively affect their psychology. Nevertheless, no statistically significant difference has been found in preservice science teachers' relationship with teachers by the variable of social media site membership duration.

It has also been concluded that no statistically significant difference exists among preservice science teachers' academic procrastination behaviours by the variable of most frequently used social media site. There is a statistically significant difference among the participants in the sharing need subdimension of preservice science teachers' social media attitude dimension by the most frequently used social media site variable. It has been found that social media sharing need of preservice science teachers that use Facebook the most often is significantly higher than the preservice teachers that use YouTube the most frequently as the social media site. Similarly, there is a statistically significant difference in science teachers' social competencies by most frequently used social media site variable. This significance exists between preservice science teachers that use Facebook the most often and the preservice teachers that use YouTube the most often. Moreover, preservice science teachers' social isolations indicate a statistically significant difference by the variable of most frequently used social media site. When the results of the analysis conducted to determine the direction of this significant difference are analysed, it is seen that 
social isolation of preservice teachers that use Instagram the most frequently is significantly higher than those using Wikipedia the most frequently. In a similar vein, the social isolation of the preservice teachers using Instagram the most often has been found to be significantly higher than the preservice teachers using YouTube the most often. Nonetheless, no statistically significant difference has been found in the subdimension of preservice science teachers' relationship with teachers by the most frequently used social media site variable.

The regression analysis results regarding the prediction of academic procrastination by the variables of the sharing need, social competency, social isolation and relationship with teachers indicate that there is a positive and low-level relationship between sharing need and academic procrastination behaviour. There is a positive and lowlevel relationship between social competency and academic procrastination behaviour. Based on the calculated scores, there is a negative and low-level relationship between social isolation as a dimension of attitude towards social media and academic procrastination behaviour. There is a positive and low-level relationship between relationship with teachers and academic procrastination behaviour. As dimensions of the attitude towards social media, the variables of sharing need, social competency, social isolation and relationship with teachers, along with preservice teachers' academic procrastination behaviours yield a low-level and significant relationship, and together with the aforementioned four variables, explain $6 \%$ of the total variance in academic procrastination behaviour.

\section{Conclusion and Suggestions}

This study attempts to determine the relationship between preservice science teachers' academic procrastination behaviours and their attitude towards social media. It has been found that, preservice science teachers' academic procrastination behaviours show a significant difference in favour of female preservice teachers by the variable of gender. In order to reduce academic procrastination behaviour displayed by preservice teachers, psychological counselling and guidance services can be provided within faculties of education. The reason behind the male preservice teachers a higher degree of academic procrastination behaviour can be analysed through future studies. Another finding of the current study is that there is a significant difference in preservice science teachers' attitudes towards social media in terms of sharing need, social competency and social isolation subdimensions by the variable of membership to social media sites. In contrast, no significant difference is found for the relationship with teachers subdimension by social media site membership variable. Similarly, no significant difference is identified in preservice science teachers' academic procrastination behaviours by social media site membership. Still, it is concluded that as the duration of preservice science teachers' social media site membership increases, so does their academic procrastination behaviour. Also, as the duration of membership to social media sites increases, the sharing need, social competency and social isolation subdimensions of attitude towards social media also increase significantly. Another conclusion is that there is no statistically significant difference in preservice science teachers' academic procrastination behaviours by the most frequently used social media site. Seminars about the appropriate use of social media can be delivered to preservice teachers in order to prevent academic procrastination behaviour resulting from the increased social media use. Preservice science teachers difference to a statistically significant degree in their sharing need, social competency and social isolation by the social media sites that they use the most frequently. The preservice teachers that use Facebook the most often have higher sharing needs and social competencies. Preservice science teachers that use Instagram the most often have higher social isolation. Yet, no statistically significant difference has been detected in the preservice science teachers' relationship with teachers subdimension by the most frequently used social media sites variable. The variables of sharing need, social competency, social isolation and relationship with teachers, together with preservice teachers' academic procrastination behaviours yield a low-level and significant relationship and with the aforementioned four variables, explain $6 \%$ of the total variance in academic procrastination behaviour. Group work or experimental intervention programs can be developed and applied that aim at reducing academic procrastination behaviours stemming from attitudes towards social media. Furthermore, such practices can be implemented with elementary and secondary school students. Such interventions may actually be more helpful if they are applied in this early period. Informing and supporting students about studying and time management may change their habits and may make these positive habits more lasting, which may help them experience fewer procrastination problems in their future higher education.

\section{References}

kar, E., 2010. Social media marketing: Social marketing strategies in the web. Ankara: Efil Publishing House.

Akinsola, M.K., A. Tella and A. Tella, 2007. Correlates of academic procrastination and mathematics achievement of university undergraduate students. Eurasia Journal of Mathematics, Science \& Technology Education, 3(4): 363-370. View at Google Scholar $\mid$ View at Publisher

Argine, F.S., 2013. Examination of the attitudes of middle school and high school students towards social media (Sample of Drawer). Unpublished Master's Thesis, Yeditepe University Institute of Social Sciences, Istanbul.

Aypay, A., M. Erdoğan and M.A. Sözer, 2007. Variation among schools on classroom practices in science based on TIMSS-1999 in Turkey. Journal of Research in Science Teaching, 44(10): 1417-1435. View at Google Scholar | View at Publisher

Balkıs, M., 2007. The tendency of teacher candidates to postpone their behavior is related to decision-making styles. Pamukkale University Journal of Education Faculty, 21(1): 67-83.

Balkıs, M., E. Duru, M. Buluş and S. Duru, 2006. Examination of the tendency of academic postponement in terms of various variables in university students. Ege Education Journal, 2(7): 57-73.

Burka, J.B. and L.M. Yuen, 1983. Procrastination: Why you do it, what to do about it. Reading, MA: Addison-Wesley.

Büyüköztürk, Ş., 2012. Data analysis handbook for social sciences. Ankara: Pegem Academy.

Çakıcı, D.Ç., 2003. Examination of general postponement and academic postponement behaviors in high school and university students. Unpublished Master's Thesis, Ankara University, Ankara.

Chickering, A.W. and F.Z. Gamson, 1987. Seven principles for good practice in undergraduate education. AAHE Bulletin, 39(7): 3-7. View at Google Scholar

Chou, C., L. Condron and J.C. Belland, 2005. A review of research on internet addiction. Educational Psychology Review, 17(4): 363-388. View at Google Scholar

Davis, D.R. and J.T. Abbitt, 2013. An investigation of the impact of an intervention to reduce academic procrastination using short message service (SMS) technology. Journal of Interactive Online Learning, 12(3): 78-102. View at Google Scholar

Day, V., D. Mensink and M. O'Sullivan, 2000. Patterns of academic procrastination. Journal of College Reading and Learning, 30(2): 120134. View at Google Scholar 
Dietz, F., M. Hofer and S. Fries, 2007. Individual values, learning routines and academic procrastination. British Journal of Educational Psychology, 77(4): 893-906. View at Google Scholar |View at Publisher

Doyle, J.A. and M.A. Paludi, 1998. Sex and gender: The human experience. Boston: McGrow Hill.

Ellis, A. and W.J. Knaus, 1977. Overcoming procrastination. New York: New American Library.

Ferrari, J.R., 1991. Compulsive procrastination: Some self-reported characteristics. Psychological Reports, 68(2): 455-458. View at Google Scholar $\mid$ View at Publisher

Ferrari, J.R., 1992. Procrastinators and perfect behavior: An exploratory factor analysis of self-presentation, self-awareness, and selfhandicapping components. Journal of Research in Personality, 26(1): 75-84. View at Google Scholar | View at Publisher

Ferrari, J.R., 2000. Procrastination and attention: Factor analysis of attention deficit, boredomness, intelligence, self-esteem, and task delay frequencies. Journal of Social Behavior and Personality, 15(5): 185-196. View at Google Scholar

Ferrari, J.R., 2010. Still procrastinating? The no regret guide to getting it done. New York: J.Wiley \& Sons, Inc.

Haycock, L.A., 1993. The cognitive mediation of procrastination: An investigation of the relationship between procrastination and selfefficacy beliefs. Doctoral Dissertation, University of Minnesota.

Hen, M. and M. Goroshi, 2014. Academic self-efficacy, emotional intelligence, gpa and academic procrastination in higher education. Eurasian Journal of Social Sciences, 2(1): 1-10. View at Google Scholar

Humprey, P. and J. Harbin, 2010. An explaratory study of the effect of rewards and deadlines on academic procrastination in web-based classes. Academy of Educational Leadership Journal, 14(4): 91-98. View at Google Scholar

Johnson, E.M., K.E. Green and R.C. Kluever, 2000. Psychometric characteristics of the revised procrastination inventory. Research in Higher Education, 41(2): 269-271. View at Google Scholar

Junco, R., 2012. The relationship between frequency of facebook use, participation in facebook activities, and student engagement. Computers \& Education, 58(1): 162-171. View at Google Scholar $\mid$ View at Publisher

Kachgal, M.M., S. Hansen and J. Nutter, 2001. Academic procrastination prevention/mtervation: Strategies and recommedations. Journal of Developmental Education, 25(1): 14-24. View at Google Scholar

Kandell, J., 1998. Internet addiction on campus: The vulnerability of college students. Cyberpsychology \& Behavior, 1(1): 11-17. View at Google Scholar $\mid$ View at Publisher

Karasar, N., 2000. Scientific research method. Ankara: Nobel Yayin Dagitim.

Kirschner, P.A. and A.C. Karpinski, 2010. Facebook and academic performance. Computers in Human Behavior, 26(6): 1237-1245. View at Google Scholar $\mid$ View at Publisher

Klassen, R.M. and E. Kuzucu, 2009. Academic procrastination and motivation of adolescents in Turkey. Educational Psychology, 29(1): 6981. View at Google Scholar $\mid$ View at Publisher

Kraut, R., M. Patterson, V. Lundmark, S. Kiesler, T. Mukophadhyay and W. Scherlis, 1998. Internetparadox: A social technology that reduces social involvement and psychological well-being. American Psychologist, 53(9): 1017-1031. View at Google Scholar | View at Publisher

Kubey, R.W., M.J. Lavin and J.R. Barrows, 2001. Internet use and collegiate academic performance decrements: Early findings. Journal of Communication, 51(2): 366-382. View at Google Scholar $\mid$ View at Publisher

Mayfield, A., 2008. What is social media. UK: iCrossing. Retrieved from http://www.icrossing.com/uk/ [Accessed March 13, 2015].

Oguz, B., N. Zayim, D. Özel and O. Saka, 2008. Cognitive states of medical students. Academic Information Congress, Çanakkale Onsekiz Mart University, 30 January-0 1 February, Çanakkale.

Onwuegbuzie, A.J., 2000. Academic procrastinators and perfectionistic tendencies among graduate students. Journal of Social Behavior and Personality, 15(5): 103-110. View at Google Scholar

Otrar, M. and F.S. Argun, 2013. A scale development study to determine students' attitudes towards social media. 7 th International Symposium on Computer and Instructional Technologies (ICITS), Erzurum, Atatürk University.

Potts, T.J., 1987. Predicting procrastination on academic tasks with self-report personality measures. Doctoral Dissertation, Hofstra University.

Prohaska, V., P. Morrill, I. Atiles and A. Perez, 2000. Academic procrastination by nontraditional students. Journal of Social Behavior and Personality, 15(5): 125-135. View at Google Scholar

Pychyl, T.A., J.M. Lee, R. Thibodeau and A. Blunt, 2000. Five days of emotion: An experience sampling study of under graduate student procrastination. Journal of Social Behavior and Personality, 15(5): 239-254. View at Google Scholar

Schouwenburg, H.C., 2004. Academic procrastination: Theoretical notions, measurement, and research. In H. C. Schouwenburg, C. H. Lay, T. A. Pychyl, \& J. R. Ferrari (Eds.), Counseling the procrastinator in academic settings. Washington, DC: American Psychological Association. pp: 3-17.

Senécal, C., R. Koestner and R.J. Vallerand, 1995. Self-regulation and academic procrastination. Journal of Social Psychology, 135(5): 607619. View at Google Scholar |View at Publisher

Silver, M. and J. Sabini, 1981. Procrastinating. Journal of Theory of Social Behavior, 11(2): 207-221. View at Google Scholar

Solomon, L.J. and E.D. Rothblum, 1984. Academic procrastination: Frequency and cognitive-behavioral correlates. Journal of Counseling Psychology, 31 (4): 503-509. View at Google Scholar | View at Publisher

Waight, N. and F. Abd-El-Khalick, 2007. The impact of technology on their enactment of "inquiry" in a technology enthusiast's sixth grade science classroom. Journal of Research in Science Teaching, 44(1): 154-182. View at Google Scholar $\mid$ View at Publisher

Washington, J.A., 2004. The relationship between procrastination and depression among graduate and professional students across academic programs: Implications for counseling. Unpublished Doctoral Dissertation. Texas Southern University.

Young, A.R., 2004. The incidental fortress: The single European market and world trade. Journal of Common Market Studies, 42(2): 393414. View at Google Scholar | View at Publisher 